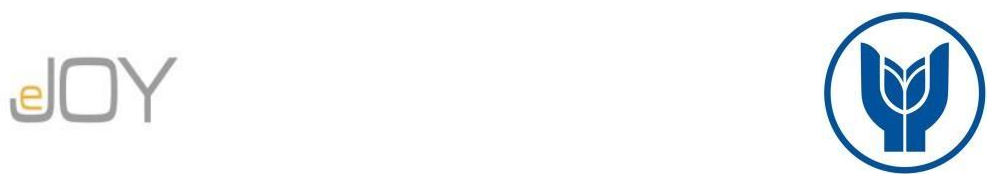

Ataklı Yavuz, R., Davasligil Atmaca, V. / Journal of Yasar University, 2020, 15/57, 84-97

\title{
Türk Döviz Piyasasında Haftanın Günü Anomalisinin Analizi
}

\section{The Analysis Of The Weekday Anomaly On Turkish Foreign Exchange Market}

\author{
Rüya ATAKLI YAVUZ, Çanakkale Onsekiz Mart Üniversitesi, Türkiye. ruyaatakli@comu.edu.tr \\ Orcid No: 0000-0003-3147-333X \\ Verda DAVASLIGILL ATMACA, Çanakkale Onsekiz Mart Üniversitesi; Türkiye. verdaatmaca@ comu.edu.tr \\ Orcid No: 0000-0002-9124-4347
}

\begin{abstract}
Öz: Finansal piyasalarda işlem gören varlıkların fiyatlanmasinda haftanın günü etkisi, ay etkisi ve tatil etkisi gibi takvimsel anomaliler oldukça sık görülmektedir. Literatürde, Etkin Piyasalar Hipotezi ile uyuşmayan bu anomalilerin varlığının araștırıldı̆̆ı çalışmalar hisse senedi piyasaları üzerine yoğunlaşmıştır. Döviz piyasalarında ortaya çıkabilecek takvimsel anomalilerin tespitine yönelik çalışmalar ise oldukça sinırlı sayıdadır. Oysaki, döviz kuru piyasalarında ortaya çıkan anomaliler portföy yöneticilerinin alacakları risk ve kararlar bakımından önem taşımaktadır. Bu çalışmanın amacı, 04.05.2010- 02.05.2019 dönemi için TL/\$ ve TL/Euro döviz kuru getiri serilerinde haftanın günü etkisinin var olup olmadı̆̆ının tek değişkenli GARCH modeller ile analiz edilmesidir.Analiz bulgularına göre söz konusu dönemde haftanın bazı günlerinde hem TL/\$ hem de TL/Euro döviz getiri serilerinde haftanın günü etkisinin bulunduğu sonucuna varllmıştır.
\end{abstract}

Anahtar Sözcükler: Döviz Piyasası, Takvimsel Anomaliler, Haftanın Günü Etkisi, Etkin Piyasalar Hipotezi, GARCH Model, Volatilite JEL Siniflandırmast: C22, E44, P34, F31

Abstract: The calendar anomalies such as weekday anomaly, month anomaly, and holiday effect on the pricing of assets traded in financial markets are frequently seen. In literature, the studies carried out on examining the presence of these anomalies contradicting with the Efficient Market Hypothesis have focused on the stock-exchange markets. The number of studies on possible calendar anomalies to occur in foreign exchange markets is limited. However, the anomalies to occur in foreign exchange markets are important from the aspect of risks taken and decisions made by the portfolio managers. Using the single-variable GARCH models, the objective of this study is to analyze if there is weekday effect on the TL $\$$ and TL/Euro foreign exchange gains for the period between 05.04.2010 and 05.02.2019. According to the findings of the analysis, it is concluded that there is a day of the week effect on both TL / \$ and TL / Euro foreign exchange return series in some days of the week in the said period.

Keywords: Foreign Exchange Market, Calendar Anomalies, Weekday Effect, Efficient Market Hypothesis, GARCH Model, Volatility JEL Classification: C22, E44, P34, F31

\section{Giriş}

Fama (1970) tarafindan ortaya atılan “Etkin Piyasalar Hipotezi”ne göre finansal piyasalarda fiyat hareketleri rastgele oluşmakta ve tesadüfi dağılım göstermektedir. Buna göre finansal piyasalarda fiyat hareketleri önceden tahmin edilememektedir. Etkin bir finansal piyasada yatırımcılar tüm bilgiye özgürce sahip olabilmekte, piyasada işlem gören bütün menkul kıymetleri istedikleri miktarda alıp satabilmektedir (Madura, 1998: 9). Etkin piyasalar hipotezi, menkul kıymet fiyatlarının rastgele yürüyüş sergiledikleri için herhangi bir model tarafindan tahmin edilemeyeceğini ileri sürmektedir. (Bayraktar, 2012, 39). Etkin piyasalar hipotezi temelde 3 varsayım üzerine inşa edilmiştir. Bu varsayımlar şöyle sıralanabilir: ilk olarak yatırımcıların rasyonel oldukları varsayılmaktadır. İkinci varsayım yatırımcıların tam bilgiye sahip olduklarını ifade etmektedir. Son olarak da yatırımcıların faydalarını maksimize etmeyi umdukları ve fayda maksimizasyonuna yönelik davranış sergiledikleri varsayılmaktadır.

Piyasaların etkinlik derecelerine göre zayıf formda, yarı güçlü formda ve güçlü formda olmak üzere üçlü bir sınıflandırma yapılabilir (Fama, 1970). Zayıf form, hipotezin ilk ve en basit biçimde ifade edilmişşekli olarak bilinir. Literatürde zayıf form, rastsal yürüyüş hipotezi olarak da adlandırılmışır. Etkin piyasalar hipotezinin zayıf formuna göre hisse senedi fiyatlarıyla ilgili bütün geçmiş bilgilere kolayca ulaşılabilir. Ayrıca geçmiş fiyat ve getiri bilgileriyle aşırı kazanç sağlamak imkansızdır (Shleifer, 2000, 6). Yarı güçlü formda fiyatlar üzerinde etki edebilecek herhangi bir bilgi kamuya açıklandığı an fiyatlara yansıyacaktır. Dolayısıyla yatırımcı ileriye yönelik kendine avantaj sağlayacak bir getiri tahmini yapamayacak ve aşırı kar elde edemeyecektir. Kısaca yarı güçlü form, kamuya açık bilgileri kullanan yatıımcıların aşırı kâr sağlama olanağının olmadığını iddia etmektedir (Tufan ve Sarıçiçek, 2013, 166). Teorik olarak eğer piyasada bir finansal varlığın aşırı getirisi tahmin edilemiyorsa ve bütün bilgiler tüm piyasa katılımcıları tarafından elde edilebilir durumda ise güçlü piyasa etkinliği vardır. Etkin piyasalar hipotezine göre, finansal piyasada fiyatlar piyasa güçlerinin etkisiyle denge fiyatı seviyesine ulaşacaktır. Bu hipotezde irrasyonel davranışın finansal piyasalar üzerindeki etkisi önemsizdir ve göz ardı edilmektedir (Lo, 2004, 7).

Etkin piyasalar hipotezinin ampirik olarak kanıtlanması çabalarında genellikle doğrusallık test edilmektedir. Bu durumda yatırımcı davranışlarının da doğrusal olduğu varsayılmaktadır. Fakat, teorik varsayımların aksine gerçek yaşamda yatırımcıların risk ve getiriye verdikleri tepkilerin her zaman doğrusal olduğu söylenemez. (Champell vd., 1996, 22). Pek çok defa finansal piyasalarda anomaliler gözlemlendiği ampirik çalışmalar ile kanıtlanmıştır. Özellikle piyasaların "zayıf formda etkinliğini" incelemek için "takvimsel anomalilerin bulunup bulunmadığı" test edilmektedir

Makale Gecmiși / Article History

Başvuru Tarihi / Date of Application

Kabul Tarihi / Acceptance Date

: 16 Ağustos / August 2019

: 14 Ekim / October 2019 
(Barak ve Demireli, 2002). Bu çalışmada TL/\$ ve TL/Euro döviz kuru getiri serilerinde haftanın günü anomalisinin var olup olmadığının tek değişkenli GARCH modeller ile analiz edilmiştir.

\section{Literatür Taraması}

Anomali, kavramsal olarak 'teoriyle uyuşmayan gerçeklik ve gözlem' olarak tanımlanabilir (Özarı ve Turan, 2016,1606). Brav ve Heaton (2002)' a göre, finansal piyasalarda gözlenen anomaliler etkin piyasalar hipotezi ile uyuşmayan getiri ya da fiyat davranış modeli sergilemektedirler. Öyleyse etkin piyasalar hipoteziyle uyuşmayan ampirik bir bulgu anomali olarak değerlendirilmektedir.

Etkin piyasalar hipotezine göre; getiri zamandan bağımsızdır yani haftanın bir gününün getirisi diğer günlerin getirisinden istatistiki olarak anlamlı şekilde farklılaşmamaktadır. Fakat yapılan pek çok ampirik çalışmada finansal piyasalarda haftanın bazı günlerinin diğer günlere nazaran daha yüksek veya daha düşük getiri sağladığı yani etkin piyasalar ile uyuşmadığı yönünde bulgular elde edilmiştir (Erdoğan ve Elmas, 2010, 281). Dolayısıyla finansal piyasalarda anomalilerin gözlemlendiği ampirik bulgular yoluyla pek çok kez ortaya konulmuştur denilebilir.

Finansal piyasalarda gözlemlenen anomaliler; takvimsel anomaliler ve fiyat anomalileridir. Takvimsel anomaliler, belirli bir zaman diliminin öncesi ya da sonrası gözlenen anomaliler (gün içi, günlere ilişkin, aylara ilişkin ve tatillere ilişkin anomaliler) olarak çok çeşitli biçimlerde ortaya çıkmaktadır. Fiyat anomalileri ise, yatırımcıların aşırı reaksiyonu ve düşük reaksiyonundan kaynaklanan, piyasa etkinliğinden sapma durumunu ifade etmektedir (Sümer ve Aybar 2016, 78). Piyasaların zayıf formda etkinliğini incelemek için takvimsel anomalilerin bulunup bulunmadığı test edilmektedir (Barak ve Demireli, 2002).

Fama başta olmak üzere kimi araştırmacılar, finansal piyasalarda görülen anomalilerin tamamen tesadüfen ortaya çıktığı ve etkin piyasalar hipotezine herhangi bir tehdit oluşturmadığı görüşünü savunmaktadırlar. Bont, Thaler ve Schleifer gibi diğer bazı araştırmacılar ise anomalilerin yatırımcıların rasyonel olmayan davranışlarının sonucu olduğu görüşündedirler (Rodriguez, 2002, 2). Yapılan pek çok çalışmada rasyonel olmayan birtakım davranışların yatırımcılar tarafından sürekli olarak tekrarlandıkları ve böylece finansal piyasalarda bazı anomalilerin sürekli olarak gözlemlenebildiği yönünde bulgular elde edilmiştir (Erdoğan ve Elmas, 2010, 280).

Coats (1981), McFarland ve diğerleri (1982), Hilliard ve Tucker (1992), Cornett ve diğerleri (1995), Thatcher ve Blenman (2001) çalışmalarında döviz piyasasında takvimsel anomalilerin olup olmadığını ampirik olarak analiz etmişler ve çeşitli takvimsel anomalilerin varlığını tespit etmişlerdir. Kamstra ve diğerleri (1999) çalışmalarında döviz piyasasında haftanın günü ve hafta sonu etkisinin görüldüğünü belirtmişlerdir. Pettengill de (2003) çalışmasında hem tahvil piyasasında ve hem de döviz piyasasında haftanın günü etkisinin var olduğunu belirtmiştir.

Liano ve Kelly (1995) yapmış oldukları çalışmada 1977-1987 yılları arasında futures döviz piyasasında Dolar karşısında Mark, Pound ve Yen için ay dönümü etkisinin var olup olmadığını test etmişlerdir. Çalışmadan elde edilen bulgulara göre, Yen futures sözleşmelerinde ay dönümü etkisi tespit edilmiştir.

Yamori ve Mourdoukoutas (2003) çalışmalarında 1973-1989 yılları arası ve 1990'lı yıllar için Dolar/Yen kuruna ilişkin getiri serisinde haftanın günü etkisi anomalisinin olup olmadığını araştırmışlardır. Ampirik analizin bulgularına göre 1973- 1989 yılları arası haftanın günü etkisi anomalisinin varlığı tespit edilmiştir. 1990’lı yıllarda ise söz konusu anomalinin varlığına ilişkin bulgu elde edilmemiştir.

Aydoğan ve Boot (2003), Türk döviz piyasası için yaptıkları çalışmada 1986-1994 yılları arasında Dolar/TL ve Mark/TL kurlarına ilişkin serbest piyasa verilerini (Tahtakale) ve resmi verileri (Merkez Bankası) kullanarak takvimsel anomalilerin olup olmadığını test etmişlerdir. Çalışmanın bulgularına göre, serbest döviz piyasasında haftanın günü etkisi, ayın haftası etkisi ve tatil etkisi anomalilerinin gözlemlendiği belirtilmiştir. Resmi kurlar da ise söz konusu anomalilere rastlanmamıştır.

Yamori ve Kurihara (2004) çalışmalarında New York döviz piyasasında işlem gören yabancı paralardan 29 döviz kuru için haftanın günü etkisinin olup olmadığını 1980'li ve 1990’lı yıllar için ayrı ayrı incelemiş ve 1980'li yıllarda bazı para birimlerinde haftanın günü etkisinin var olduğu sonucuna varmışlardır. Ancak çalışmanın ampirik bulgularına gore analize dahil edilen hiçbir para birimi için 1990'lı yıllarda bu etki tespit edilememiştir.

Ke ve diğerleri (2007) Tayvan döviz piyasasında 1992-2006 yılları arasında 8 farklı para biriminin Yen karşısındaki kur değerlerini kullanarak haftanın günü etkisinin varlığını araştırmışlardır. Analiz sonuçlarına göre haftanın ilk 3 gününde elde edilen getirilerin diğer günlerden daha yüksek olduğu belirtilmiştir.

Berument ve diğerleri (2007) yapmış oldukları çalışmada Türk döviz piyasasında 2001-2005 dönemi için Dolar/TL kurunda haftanın günü etkisinin var olup olmadığını araştırmışlardır. Analiz bulgularına göre Pazartesi günleri Çarşamba günlerine nazaran dolar/TL getirisinin daha yüksek olduğu sonucuna varılmıştır.

Yu ve diğerleri (2008) yaptıkları çalışmada 1994-2003 döneminde New York, Londra ve Tokyo borsasında, Yen/Dolar spot kurlarını ele alarak haftanın günü etkisinin varlığını sınamışlardır. Çalışmanın ampirik bulgularına göre Salı günleri negatif ve haftanın diğer günlerine kıyasla daha düşük getiri elde edildiği sonucuna varılmıştır. Bunun yanında Perşembe günleri pozitif ve haftanın diğer günlerine nazaran daha fazla getiri elde edildiği belirtilmiştir.

Kumar (2015) çalışmasında 1999-2014 dönemi için Hindistan döviz piyasasında Dolar/ Rupi, Euro/Rupi, Pound/Rupi ve Yen/Rupi kurlarını ele alarak ay dönümü etkisinin var olup olmadığını test etmiştir. Analiz bulguları Dolar/Rupi ve Yen/Rupi kurlarında ay dönümü etkisinin var olduğunu yönündedir.

Kumar (2016) yapmış olduğu çalışmada 1985-2014 döneminde 12 para biriminin dolar karşısındaki getirisi için haftanın günü, Ocak ayı ve ay dönümü etkilerinin varlığını analiz etmiştir. Çalışmanın ampirik bulgularına göre 
haftanın günleri etkisinin var olduğu ve Pazartesi, Salı ve Çarşamba günleri elde edilen getirilerin pozitif, Perşembe ve Cuma günleri elde edilen getirilerin ise negatif olduğu belirtilmiştir. Ayrıca Ocak ayı etkisinin ve ay dönümü etkisinin de varlığı tespit edilmiştir. Buna göre Ocak ayındaki getirilerin yılın diğer aylarına kıyasla daha yüksek olduğu ve ay dönümlerinde negatif getiri elde edildiği yönünde sonuçlara ulaşılmıştır.

Kumar ve Pathak (2016) yaptıkları çalışmada Hindistan döviz piyasasında 1999-2014 döneminde Euro/Rupi, Pound/Rupi, Dolar/Rupi ve Yen/Rupi kurları için haftanın günü etkisi ve Ocak ayı etkisinin varlığını araştırmışlardır. Çalışmanın sonucuna göre döviz piyasasında hem haftanın günü hem de Ocak ayı etkisi vardır. Ampirik bulgular, getirilerin Pazartesi, Salı ve Çarşamba günlerinde pozitif, Perşembe ve Cuma günlerinde ise negatif olduğu yönündedir. Ayrıca Ocak ayında yılın diğer aylarına göre daha yüksek getiri elde edildiği belirtilmiştir.

Özarı ve Turan (2016), 1997-2005 dönemi için hem BIST30, BIST100 endeksleri hem de dolar kuru ile işlem vadeli işlem sözleşmelerinin getiri oranlarını dikkate alarak haftanın günü Ocak ayı etkilerinin olup olmadığını araştırmışlardır. Çalışmanın ampirik bulgularına göre BIST30 ve BIST100 endekslerinde gün etkisi bulunmamıştır. Bunun yanında dolar kurunda Pazartesi ve Salı günleri, vadeli BIST30 sözleşmelerinde Çarşamba günü ve vadeli dolar sözleşmelerinde Perşembe günü getiri ortalamalarının negatif olduğu gözlemlenmiştir. Ayrıca benzer biçimde BIST30 ve BIST100 endeksleri için Ocak ayı etkisi gözlemlenmemiştir. Bunun yanında dolar, dolar ve BIST30 sözleşmeleri için Ocak ayı etkisinin var olduğu ifade edilmiştir.

Eyüboğlu ve Eyüboğlu (2018) çalışmalarında 2006-2016 dönemi için Türk döviz piyasasında haftanın günü ve Ocak ayı etkisinin varlığını Dolar/TL, Euro/TL, Frank/TL, Pound/TL, Yuan/TL döviz kurlarına ilişkin günlük getirilerden yararlanarak sınamışlardır. Çalışmadan elde edilen sonuçlar, yalnızca Dolar/TL kurunda haftanın günü anomalisinin olduğunu diğer döviz kurları için böyle bir etkinin bulunmadığını göstermektedir. Ayrıca çalışmanın bulguları, 5 farklı döviz kuru için de Ocak ayı anomalisinin olmadığını ortaya koymuştur.

Khademalomoom ve Narayan (2019) çalışmalarında 6 farklı para biriminin dolar karşısındaki 2004- 2014 yılları arasındaki gün içi kur verilerini kullanarak söz konusu para birimlerinin getiri serilerinde gün içi etkisinin olup olmadığını test etmişlerdir. Analiz bulgularına göre söz konusu para birimlerinde gün içi etkisinin varlığı tespit edilmiştir.

\section{Veri ve Metodoloji}

Çalışmanın amacı Türk Lirası'na (TRY) karşı Amerikan Doları (USD) ve Avro (EUR) serilerinde haftanın günü anomalisinin var olup olmadığının GARCH, EGARCH ve GJR-GARCH modeller kullanılarak araştırılmasıdır. Bu amaçla 04.05.2010-02.05.2019 dönemine ait veriler Türkiye Cumhuriyet Merkez Bankası Elektronik Veri Dağıtım Sisteminden elde edilerek düzenlenmiştir. 2014 yılı Mart ve Ağustos aylarında yerel seçim ve Cumhurbaşkanlığı seçimi gerçekleştirilmiştir. Analiz için ele alınan tarih aralığı incelendiğinde 2014 yılı Ekim ayında Cumhuriyet tarihinin en yüksek ihracat rakamına ulaşılmıştır. 16 Aralık 2014 tarihinde ise USD/TRY bankalararası piyasada 2.4126 seviyesi ile en yüksek noktaya ulaşmıştır. 2014 yılı Ekim-Kasım aylarından itibaren gerek USD gerekse EUR yükseliş eğilimine girmiştir. $\mathrm{Bu}$ nedenle USD ve EUR serilerinin günlük değerlerinin seyri dikkate alınarak veri seti 04.05.201031.10.2014 (Birinci dönem) ve 03.11.2014- 02.05.2019 (İkinci dönem) olmak üzere iki döneme ayrılarak analizler gerçekleştirilmiştir. USD ve EUR serilerine ait günlük ortalama logaritmik getiri serileri aşağıdaki gibi hesaplanmıştır:

$$
\begin{gathered}
\mathrm{R}_{\mathrm{t}}=100 \times\left(\log \mathrm{P}_{\mathrm{t}}-\log \mathrm{P}_{\mathrm{t}-1}\right) \\
\mathrm{r}_{\mathrm{t}}=\mathrm{R}_{\mathrm{t}}-\frac{1}{\mathrm{~T}} \sum_{\mathrm{t}=1}^{\mathrm{T}} \mathrm{R}_{\mathrm{t}}
\end{gathered}
$$

$P_{t}, t$. işgününe ait fiyatı, $\mathrm{R}_{\mathrm{t}}$ bir önceki işgününe göre logaritmik düzeyde hesaplanmış fiyat değişimini ifade etmektedir.

USD ve EUR getiri serilerinde haftanın günü etkisinin varlığını modellemek amacıyla öncelikle beş günlük kukla değişken oluşturulmuş ve otokorelasyon sorununa karşı modele getiri serisinin bir dönem gecikmeli değerleri eklenmiştir ${ }^{1}$. En Küçük Kareler Yöntemi ile tahmin edilen regresyon modelleri aşağıda gösterildiği gibidir:

$$
\begin{aligned}
& \mathrm{R}_{\mathrm{USD}_{\mathrm{t}}}=\beta_{0}+\beta_{\mathrm{p}} \text { Pazartesi }+\beta_{\mathrm{S}} \text {Sal}_{1}+\beta_{\mathrm{pe}} \text { Persembe }+\beta_{\mathrm{c}} \text { Cuma }+\beta_{1} \mathrm{R}_{\mathrm{USD}_{\mathrm{t}-1}}+\varepsilon_{\mathrm{USD}_{\mathrm{t}}} \\
& \mathrm{R}_{\mathrm{EUR}_{\mathrm{t}}}=\alpha_{0}+\alpha_{\mathrm{p}} \text { Pazartesi }+\alpha_{\mathrm{S}} \text { Sal }_{1}+\alpha_{\mathrm{pe}} \text { Persembe }+\alpha_{\mathrm{c}} \text { Cuma }+\alpha_{1} \mathrm{R}_{\mathrm{EUR}} \mathrm{t}-1+\varepsilon_{\mathrm{EUR}} \mathrm{t}
\end{aligned}
$$

Pazartesi, Salı, Perşembe ve Cuma değişkenleri haftanın günlerine ait kukla değişkenleri ifade etmektedir. Kukla değişken tuzağından kaçınmak amacıyla Çarşamba kukla değişkeni modele dahil edilmemiştir. Denklem (1) ve (2)'nin En Küçük Kareler Yöntemi ile tahmininden elde edilen sonuçlar önemli bir sorunu beraberinde getirmektedir. Bu da hata varyanslarının zaman içinde sabit olmaması diğer bir ifade ile değişen varyans sorunudur.

\footnotetext{
${ }^{1}$ USD ve EUR getiri serilerinin modellenmesinde en uygun ARMA (p,q) sürecinin belirlenmesi amaciyla farklı ARMA(p,q) modelleri tahmin edilmiştir. Tahmin edilen modeller AIC, BIC, Log-olabilirlik değerlerine göre kıyaslanmış ve en uygun model AR(1) süreci olarak belirlenmiştir.
} 
Finansal zaman serilerinde sıklıkla ortaya çıkan değişen varyans sorunu üstesinden gelinmesi gereken bir sorundur. Bu nedenle ilk olarak (1) ve (2)'nolu denklemlerin tahmini için Bollerslev (1986) tarafından önerilen Genelleştirilmiş Otoregresif Değişen Varyans (GARCH) modeli tahmin edilmiştir (Bauwens, Hafner ve Laurent, 2012:4).

GARCH (1,1) süreci aşağıdaki gibi gösterilmektedir: (Tsay, 2010:132).

$$
\varepsilon_{\mathrm{t}} \sim\left(0, \sigma_{\mathrm{t}}^{2}\right)
$$

$\varepsilon_{\mathrm{t}}$, (1) ve (2)'nolu denklemlerden elde edilen hata terimleridir.

$$
\sigma_{\mathrm{t}}^{2}=\omega+\alpha_{0} \varepsilon_{\mathrm{t} 1}^{2}+\alpha_{1} \sigma_{\mathrm{t} 1}^{2}
$$

$\omega>0, \quad \alpha_{0} \geq 0, \quad \alpha_{1} \geq 0$ ve $\alpha_{0}+\alpha_{1} \leq 1, \alpha_{0}+\alpha_{1}$ kısıtı koşulsuz varyansın sonlu olduğunu işaret etmektedir. Oysaki koşullu varyans $\sigma_{t}^{2}$ zaman içinde değişmektedir. $\varepsilon_{t}$ 'nin dağılımının standart normal, standardize Student-t dağılımı veya genelleştirilmiş hata dağılımı gösterdiği kabul edilmektedir. (3)'nolu eşitlikte yer alan GARCH model simetrik bir modeldir. Diğer bir ifade ile modelde pozitif ve negatif haberler oynaklık üzerinde aynı etkiye sahiptir. Oynaklığın asimetrik yapısını modellemek üzere alternatif GARCH modelleri önerilmiştir. Bu modeller EGARCH ve GJR -GACRH modellerdir.

Nelson (1991) tarafından önerilen $\operatorname{EGARCH}(1,1)$ model aşağıda gösterildiği gibidir:

$$
\begin{aligned}
& \varepsilon_{\mathrm{t}} \sim\left(0, \sigma_{\mathrm{t}}^{2}\right) \\
& \log \left(\sigma_{\mathrm{t}}^{2}\right)=\omega+\log \alpha_{0}\left(\sigma_{\mathrm{t} 1}^{2}\right)+\alpha_{1} \frac{\varepsilon_{\mathrm{t} 1}}{\sqrt{\sigma_{\mathrm{t} 1}^{2}}}+\gamma \frac{\left|\varepsilon_{\mathrm{t} 1}\right|}{\sqrt{\sigma_{\mathrm{t} 1}^{2}}} \sqrt{\frac{2}{\pi}}
\end{aligned}
$$

$\gamma$ katsayısının negatif değerleri oynaklık ve getiri arasındaki negatif ilişkiyi ifade etmektedir. $\gamma<0$ olması durumunda iyi haberler kötü haberlere göre oynaklığı daha az arttırmaktadır. Burada $\gamma_{\text {kaldıraç etkisini yansıtmaktadır. }}$ Analiz bölümünde tahmin edilen ikinci asimetrik GARCH model GJR-GARCH modeldir. Glosten vd. (1993) tarafından önerilen GJR-GARCH $(1,1)$ modeli aşağıda gösterildiği gibidir:

$$
\sigma_{\mathrm{t}}^{2}=\omega+\alpha_{0} \varepsilon_{\mathrm{t}-1}^{2}+\alpha_{1} \sigma_{\mathrm{t}-1}^{2}+\gamma \varepsilon_{\mathrm{t}-1}^{2} \mathrm{I}_{\mathrm{t}-1}
$$

$\mathrm{I}_{\mathrm{t} 1} \quad$ kukla değişkendir. ${ }^{2} \varepsilon_{\mathrm{t}-1}^{2}<0$ olması durumunda $\mathrm{I}_{\mathrm{t}-1}=1$, diğer durumlarda $\mathrm{I}_{\mathrm{t}-1}=0$, dır. Kaldıraç etkisi için $\gamma>0$ olması beklenmektedir. Bu durumda kötü haberler daha büyük etkiye sahiptir. $\alpha_{1}+\gamma \geq 0$ ve $\alpha_{1} \geq 0$ negatif olmama kısitlarıdır.

\section{Ampirik Sonuçlar}

TRY/USD ve TRY/EUR getiri serilerinde haftanın günü anomalisinin varlığı GARCH, EGARCH ve GJR-GARCH modeller kullanılarak araştırılmıştır. Bununla birlikte USD ve EUR getiri serilerinin ele alınan dönem içinde izledikleri seyir ve serilerin dağılımlarına ilişkin istatstikler analiz için önem arz etmektedir. USD ve EUR getiri serilerine ait zaman yolu grafiği Şekil 1'de gösterilmektedir. Her iki serinin de 2014 yılı sonlarından itibaren hızla yükselen bir seyir izlediği görülmektedir.

Şekil 1. USD ve EUR Getiri Serilerine ait Zaman Yolu Grafiği

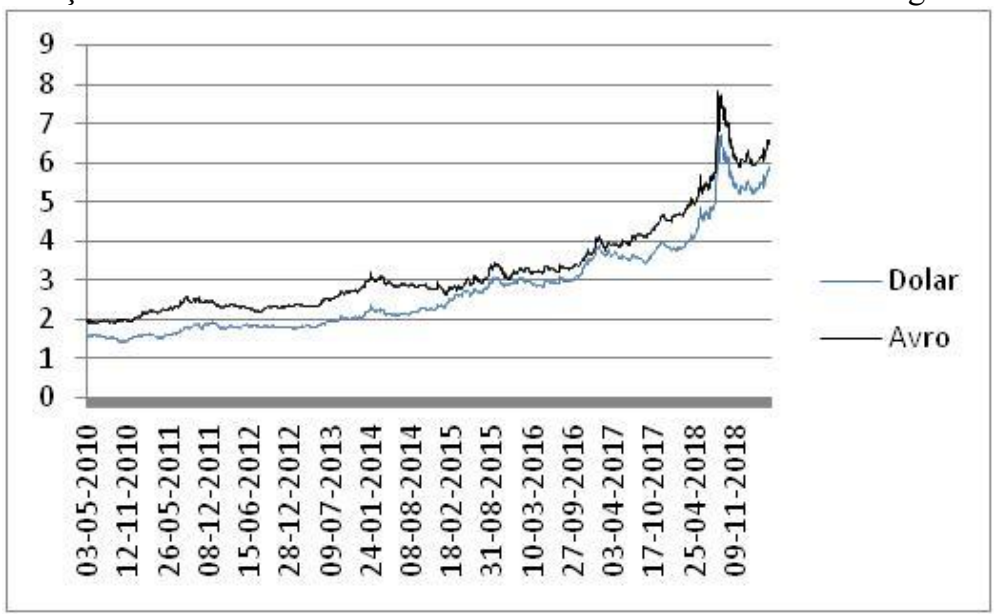


Şekil 2 ve Şekil 3'de TRY/USD ve TRY/EUR getiri serilerine ait zaman yolu grafikleri yer almaktadır. Her iki getiri serisinin de sıfır değeri etrafında pozitif ve negatif yönde dalgalandığı ayrıca belirli dönemlerde oynaklık kümelenmesi özelliği taşıdığı görülmektedir.

Şekil 2. TRY/USD Getiri Serisine ait Zaman Yolu Grafiği

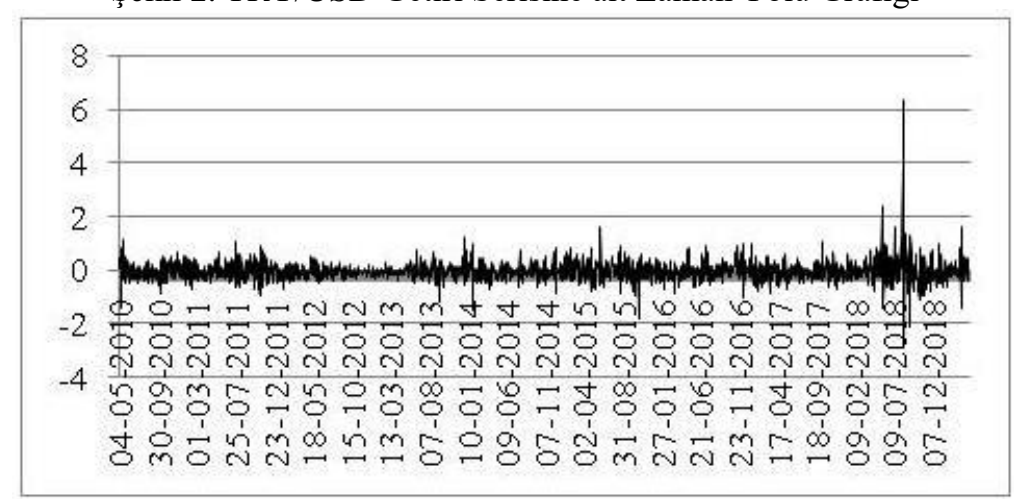

Şekil 3. TRY/EUR Getiri Serisine ait Zaman Yolu Grafiği

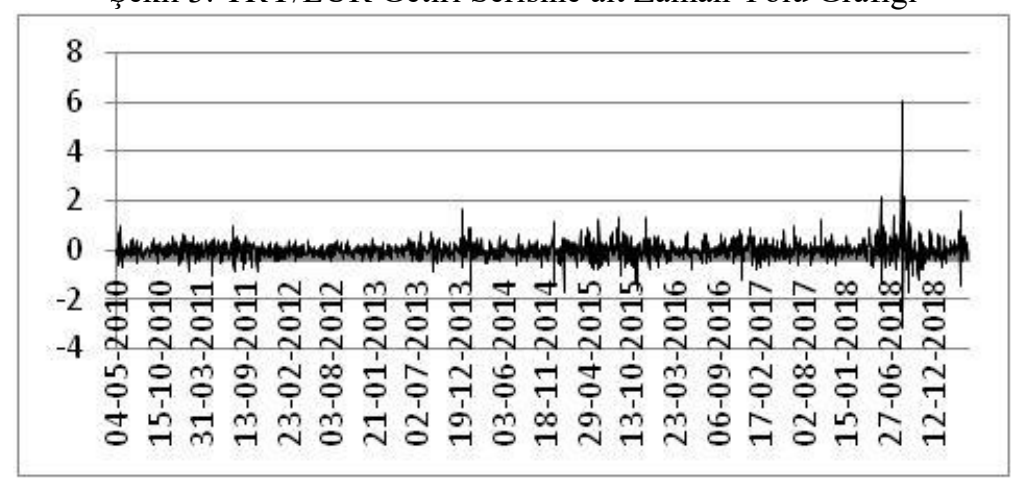

Tablo 1'de USD ve EUR getiri serilerine ait tanımlayıcı istatistikler yer almaktadır. USD ve EUR serileri çok düşük seviyede negatif ortalama getiriye sahiptir. Basıklık değerlerinin 3 değerinden oldukça yüksek olduğu aynı zamanda çarpıklık katsayılarının da 0 değerinden büyük olduğu görülmektedir. Dolayısıyla USD ve EUR getiri serileri kalın kuyruk ve sağa çarpık bir dağılıma sahiptir. Jarque-Bera test istatistiği değerleri incelendiğinde, her iki getiri serisi için, hata terimlerinin normal dağıldığını ifade eden boş hipotez 0.01 anlamlılık seviyesinde reddedilmiştir. Buna göre, USD ve EUR getiri serileri normal dağılıma sahip değildir.

Tablo 1. TRY/USD ve TRY/EUR Getiri Serilerine İlișkin Tanımlayıcı İstatistikler

\begin{tabular}{|l|l|l|}
\hline & USD & EUR \\
\hline Gözlem Sayısı & 2265 & 2265 \\
\hline Ortalama & -0.0075 & -0.0129 \\
\hline Medyan & -0.0293 & -0.0231 \\
\hline Maksimum & 6.3527 & 6.0518 \\
\hline Minimum & -2.8463 & -3.1621 \\
\hline Standart Sapma & 0.3727 & 0.3638 \\
\hline Çarpıklık & 2.6172 & 2.1896 \\
\hline Basıklık & 51.3224 & 47.1364 \\
\hline Jarque-Bera (Olasılık) & $222957.4(0.0000)$ & $185655.0(0.0000)$ \\
\hline
\end{tabular}

Tablo 2'de USD ve EUR getiri serilerine ait I(0) düzeyinde ADF ve Philips-Perron (PP) birim kök testi sonuçları yer almaktadır. ADF testine ilave olarak, PP testinin tercih edilmesinin sebebi bu testin hata terimlerinde serisel korelasyon ve değişen varyans bulunması durumunda güçlü sonuçlar vermesidir. Her iki getiri serisi için hem ADF hem de Philips-Perron test istatistiği değerleri verilen önem seviyelerinde mutlak değer olarak MacKinnon kritik değerlerinden yüksektir. Buna göre, USD ve EUR getiri serilerinde birim kök olduğunu ifade eden sıfır hipotezi reddedilmektedir. Getiri serileri seviyede durağandır. 
Tablo 2. USD ve EUR Getiri Serilerine İlişkin ADF ve PP Birim Kök Testi Sonuçları

\begin{tabular}{|c|c|c|c|}
\hline & $A D F$ & $P P$ & \\
\hline & Test İstatistiği & Test İstatistiği & Kritik Değerler \\
\hline$U S D$ & -30.0556 & -41.6109 & \multirow{2}{*}{$\begin{array}{l}-3.4330 * \\
-2.8626 * * \\
-2.5673 * * *\end{array}$} \\
\hline EUR & -29.7406 & -39.7521 & \\
\hline
\end{tabular}

Tablo 3'de USD getiri serisinin haftanın günlerine göre düzenlenmiş tanımlayıcı istatistik değerleri yer almaktadır. USD getiri serisi yalnızca salı günleri pozitif ortalama getiriye sahiptir. Bu gün aynı zamanda serinin en fazla oynaklığa sahip olduğu gündür. Çarpıklık değerleri serinin pazartesi ve salı günleri pozitif yönde çarpık diğer günler negatif yönde çarpık dağılıma sahip olduğunu göstermektedir. Günlere ilişkin basıklık değerleri tüm günler için üç değerinin üzerindedir. Jarque-Bera normallik testi sonuçları serinin haftanın tüm günleri için normal dağılıma sahip olmadığı bilgisini desteklenmektedir.

Tablo 3. USD Getiri Serisinde Haftanın Günlerine İlişkin Tanımlayıcı İstatistikler

\begin{tabular}{|l|l|l|l|l|l|}
\hline & Pazartesi & Salı & Çarşamba & Perşembe & Cuma \\
\hline Gözlem Sayısı & 454 & 450 & 455 & 452 & 454 \\
\hline Ortalama & -0.0026 & 0.0254 & -0.0061 & -0.0236 & -0.0304 \\
\hline Medyan & -0.0342 & 0.0007 & -0.0296 & -0.0331 & -0.0512 \\
\hline Maksimum & 4.1068 & 6.3527 & 1.6079 & 2.4393 & 1.6564 \\
\hline Minimum & -2.0677 & -1.7280 & -2.1908 & -2.8463 & -2.4933 \\
\hline $\begin{array}{l}\text { Standart } \\
\text { Sapma }\end{array}$ & 0.3672 & 0.4639 & 0.3071 & 0.3391 & 0.3679 \\
\hline Çarpıklık & 3.0974 & 5.6877 & -0.5611 & -0.5351 & -0.1959 \\
\hline Basıklık & 39.2381 & 79.3635 & 11.4667 & 19.5468 & 8.8724 \\
\hline $\begin{array}{l}\text { Jarque-Bera } \\
\text { (Olasılık) }\end{array}$ & $\begin{array}{l}25567.32 \\
(0.0000)\end{array}$ & $\begin{array}{l}111764.8 \\
(0.0000)\end{array}$ & $\begin{array}{l}1382.925 \\
(0.0000)\end{array}$ & $\begin{array}{l}5178.121 \\
(0.0000)\end{array}$ & $\begin{array}{l}655.251 \\
(0.0000)\end{array}$ \\
\hline
\end{tabular}

EUR getiri serisinin haftanın günlerine göre düzenlenmiş tanımlayıcı istatistik değerleri Tablo 4'de yer almaktadır. EUR getiri serisi yalnızca salı günleri pozitif ortalama getiriye ve en yüksek oynaklığa sahiptir. Çarpıklık değerleri, serinin pazartesi ve salı günleri pozitif yönde, haftanın diğer günlerinde ise negatif yönde çarpık bir dağılıma sahip olduğunu göstermektedir. Günlere ilişkin basıklık değerleri tüm günler için üç değerinden oldukça yüksektir. Bunlara ek olarak Jarque-Bera normallik testi sonuçları da serinin haftanın tüm günleri için normal dağılıma sahip olmadığı bilgisini desteklenmektedir.

Tablo 4. EUR Getiri Serisinde Haftanın Günlerine İlişkin Tanımlayıcı İstatistikler

\begin{tabular}{|l|l|l|l|l|l|}
\hline & Pazartesi & Sall & Çarşamba & Perşembe & Cuma \\
\hline Gözlem Sayısı & 454 & 450 & 455 & 452 & 454 \\
\hline Ortalama & -0.0121 & 0.0034 & -0.0085 & -0.0244 & -0.0231 \\
\hline Medyan & -0.0293 & -0.0264 & -0.0146 & -0.0280 & -0.0239 \\
\hline Maksimum & 3.6178 & 6.0518 & 1.4316 & -0.0280 & 1.5565 \\
\hline Minimum & -1.7558 & -1.6490 & -2.1027 & -3.1621 & -2.3236 \\
\hline $\begin{array}{l}\text { Standart } \\
\text { Sapma }\end{array}$ & 0.3806 & 0.4376 & 0.2970 & 0.3462 & 0.3446 \\
\hline Çarpıklık & 1.8517 & 6.1647 & -0.6815 & -1.3612 & -0.3794 \\
\hline Basıklık & 23.5553 & 84.6041 & 11.7645 & 21.2248 & 9.5315 \\
\hline $\begin{array}{l}\text { Jarque-Bera } \\
\text { (Olasıllk) }\end{array}$ & $\begin{array}{l}8252.195 \\
(0.0000)\end{array}$ & $\begin{array}{l}127711.1 \\
(0.0000)\end{array}$ & $\begin{array}{l}1491.539 \\
(0.0000)\end{array}$ & $\begin{array}{l}6394.995 \\
(0.0000)\end{array}$ & $\begin{array}{l}817.9003 \\
(0.0000)\end{array}$ \\
\hline
\end{tabular}

Tablo 5'de sırasıyla USD ve EUR getiri serileri için AR(1) model sonuçları gösterilmektedir. Tahmin edilen regresyonlarda haftanın günleri kukla değişken olarak modele dahil edilmiş ve temel sınıf Çarşamba günü olarak belirlenmiştir. Katsayılara ilişkin standart hata ve olasılık değerleri incelendiğinde, haftanın günleri için ortalama getiri katsayılarının istatistiki olarak anlamlı olmadığı görülmektedir. Buna göre, USD ve EUR getiri serileri için Pazartesi, Salı, Perşembe ve Cuma günlerindeki getiriler Çarşamba gününe kıyasla istatistiki olarak daha yüksek ya da daha düşük değerli değildir. 
Tablo 5. Regresyon Modellerine Ait Sonuçlar

\begin{tabular}{|c|c|c|c|c|}
\hline \multicolumn{5}{|c|}{ Model 1-USD Getiri Serisi için AR(1) Model Tahmin Sonuçları } \\
\hline & Katsayı & Standart Hata & t-İstatistiği & Olasılık \\
\hline Sabit & -0.0064 & 0.0174 & -0.3695 & 0.7117 \\
\hline Pazartesi & 0.0020 & 0.0244 & 0.0824 & 0.9343 \\
\hline Sall & 0.0314 & 0.0231 & 1.3554 & 0.1754 \\
\hline Perşembe & -0.0163 & 0.0231 & -0.7045 & 0.4812 \\
\hline Cuma & -0.0229 & 0.0244 & -0.9369 & 0.3489 \\
\hline$A R(1)$ & 0.1262 & 0.0208 & 6.0459 & 0.0000 \\
\hline \multicolumn{5}{|c|}{ Model 2-EUR Getiri Serisi için AR(1) Model Tahmin Sonuçlarl } \\
\hline & Katsayı & Standart Hata & t-İstatistiği & Olasılık \\
\hline Sabit & -0.0085 & 0.0170 & -0.4985 & 0.6181 \\
\hline Pazartesi & -0.0053 & 0.0237 & -0.2258 & 0.8213 \\
\hline Sall & 0.0114 & 0.0221 & 0.5161 & 0.6058 \\
\hline Perşembe & -0.0152 & 0.0220 & -0.6884 & 0.4913 \\
\hline Cuma & -0.0132 & 0.0237 & -0.5588 & 0.5763 \\
\hline$A R(1)$ & 0.1662 & 0.0207 & 8.0077 & 0.0000 \\
\hline
\end{tabular}

Not: USD ve EUR getiri serileri için en uygun ARMA $(p, q)$ sürecinin belirlenmesi amacıyla farkl ARMA(p,q) modelleri tahmin edilmiştir. Tahmin edilen modeller AIC, BIC, Log-olabilirlik değerlerine göre klyaslanmış ve en uygun model AR(1) süreci olarak belirlenmiştir.

Tablo 5'de sonuçlarına yer verilen regresyon modellerinden elde edilen artıkların varyansının sabit olması beklenmektedir. Aksi takdirde regresyon tahminlerinden elde edilen sonuçlar tutarlı ve güvenilir olmamaktadır. Tablo 6'da 1 ve 2'nolu modellerden elde edilen artıklara ilişkin ARCH-LM testi sonuçları yer almaktadır. Buna göre, her iki regresyon modeli için 0.01 anlamlılık düzeyinde sabit varyans varsayımı reddedilmektedir. Diğer bir ifade ile değişen (farklı) varyans sorunu bulunmaktadır. Bu nedenle çalışmaya değişen varyans yapısına izin veren $\mathrm{GARCH}(1,1)$, EGARCH $(1,1)$ ve GJR-GARCH $(1,1)$ modellerinin tahmini ile devam edilmektedir.

Tablo 6. ARCH -LM Testi Sonuçları

\begin{tabular}{|l|c|c|}
\hline & Model 1 & Model 2 \\
\hline F-istatistiği & 1119.670 & 1146.903 \\
\hline Prob. F(1, 2261) & 0.0000 & 0.0000 \\
\hline$T^{*} R^{2}$ & 749.5003 & 761.5947 \\
\hline Olasılık $\chi^{2}(1)$ & 0.0000 & 0.0000 \\
\hline
\end{tabular}

Tablo 7'de USD getiri serisi için GARCH, EGARCH ve GJR-GARCH model tahminlerine ilişkin sonuçlar yer almaktadır. Birinci ve ikinci dönem için tahmin edilen GARCH modeline ilişkin sonuçlar incelendiğinde, ARCH ve GARCH parametrelerinin toplamının 1'den küçük değerli olduğu görülmektedir. Buna göre, GARCH model için durağanlık koşulu sağlanmıştır. Birinci. dönem ortalama denkleminde yalnızca sabit terim 0.10 anlamlılık düzeyinde istatistiki olarak anlamlıdır. Koşullu varyans denkleminde ise denkleme dahil edilen haftanın günleri kukla değişkenlerinin istatistiki olarak anlamlı olmadığı görülmektedir. Buna göre, haftanın günleri arasında getiri oynaklığı bakımından istatistiki olarak anlamlı bir farklılık bulunmamaktadır. ARCH katsayısı pozitif değerli ve istatistiki olarak anlamlıdır. Buna göre belirli bir güne ait getiriler bir önceki güne ait getirilerden etkilenmektedir. GARCH katsayıları pozitif ve istatistiki olarak anlamlıdır. Böylece, eğer belirli bir günde seride ortaya çıkan oynaklık şoku pozitif ise bir sonraki günde de pozitif oynaklık şoku ortaya çıkacaktır. İkinci dönemde ortalama denklemi için istatistiki olarak anlamlı bir haftanın günü etkisi bulunmamaktadır. Öte yandan, koşullu varyans denklemi incelendiğinde 0.05 anlamlılık düzeyinde Salı, Perşembe ve Cuma günlerine ilişkin katsayılar istatistiki olarak anlamlıdır. Buna göre oynaklık Salı, Perşembe ve Cuma günü Çarşamba gününe kıyasla daha fazladır. GED katsayısı istatistiki olarak anlamlı, pozitif değerli ve 2 değerinden küçüktür.

Tablo 7'de yer alan EGARCH modellere ilişkin tahmin sonuçları ele alındığında, ortalama denklemlerinde birinci ve ikinci dönem için sırasıyla yalnızca sabit terim ve Cuma günü 0.10 önem seviyesinde istatistiki olarak anlamlıdır. Buna göre, ortalama USD getirisi üzerinde haftanın günü etkisi bulunmaktadır. Koşullu varyans denklemleri incelendiğinde, ilk dönem için sabit terim ve Cuma günü 0.10 önem seviyesinde istatistiki olarak anlamlıdır. Buna göre, oynaklık Çarşamba günleri diğer günlere kıyasla daha az Cuma günleri ise daha fazladır. Birinci dönem için işaret etkisini gösteren Theta 1 katsayısı 0.05 önem seviyesinde istatistiki olarak anlamlı ve pozitif değerlidir. Buna göre, pozitif şoklar negatif şoklara kıyasla daha fazla istikrar bozucu niteliktedir. Büyüklük etkisini ifade eden Theta 2 katsayısı da 0.05 önem seviyesinde istatistiki olarak anlamlıdır. İkinci dönem için elde edilen sonuçlara göre, Cuma günleri ortalama getiri Çarşamba gününe kıyasla daha düşük seviyededir. Salı ve Cuma günleri oynaklık Çarşamba gününe kıyasla daha fazladır. İşaret etkisi ise pozitif şokların negatif şoklara kıyasla daha fazla istikrar bozucu nitelikte 
olduğunu göstermektedir. Büyüklük etkisine göre, ortalama getiri ve oynaklık arasında pozitif ilişki bulunmaktadır. Her iki dönem için GED katsayısı pozitif değerli ve istatistiki olarak anlamlıdır.

Tablo 7'de yer alan GJR-GARCH model ele alındığında, her iki dönemde de ortalama denkleminde yer alan haftanın günü kukla değişkenleri istatistiki olarak anlamlı değildir. Buna göre, ortalama USD getirisi bakımından haftanın günleri arasında bir farklılık bulunmamaktadır. Koşullu varyans denklemi incelendiğinde yalnızca ikinci dönem için Salı ve Cuma günü 0.10 önem seviyesinde istatistiki olarak anlamlı bulunmuştur. Dolayısıyla, Çarşamba gününe kıyasla Salı ve Cuma günleri oynaklık daha fazladır. ARCH ve GARCH katsayıları istatistiki olarak anlamlıdır. Ayrıca GJR modelin geçerliliği için gerekli olan negatif olmama kısıtları da sağlanmıştır. Buna göre, GARCH $\geq 0$ GARCH+GJR $\geq 0$ olarak elde edilmiştir. GJR katsayısı ise kaldıraç etkisini ifade etmektedir. Ancak her iki dönemde de katsayı istatistiki olarak anlamlı olmasına rağmen pozitif işaret beklentisini karşılamamaktadır.

Tablo 7. USD Getiri Serisi için GARCH, EGARCH ve GJR-GARCH Model Tahmin Sonuçları

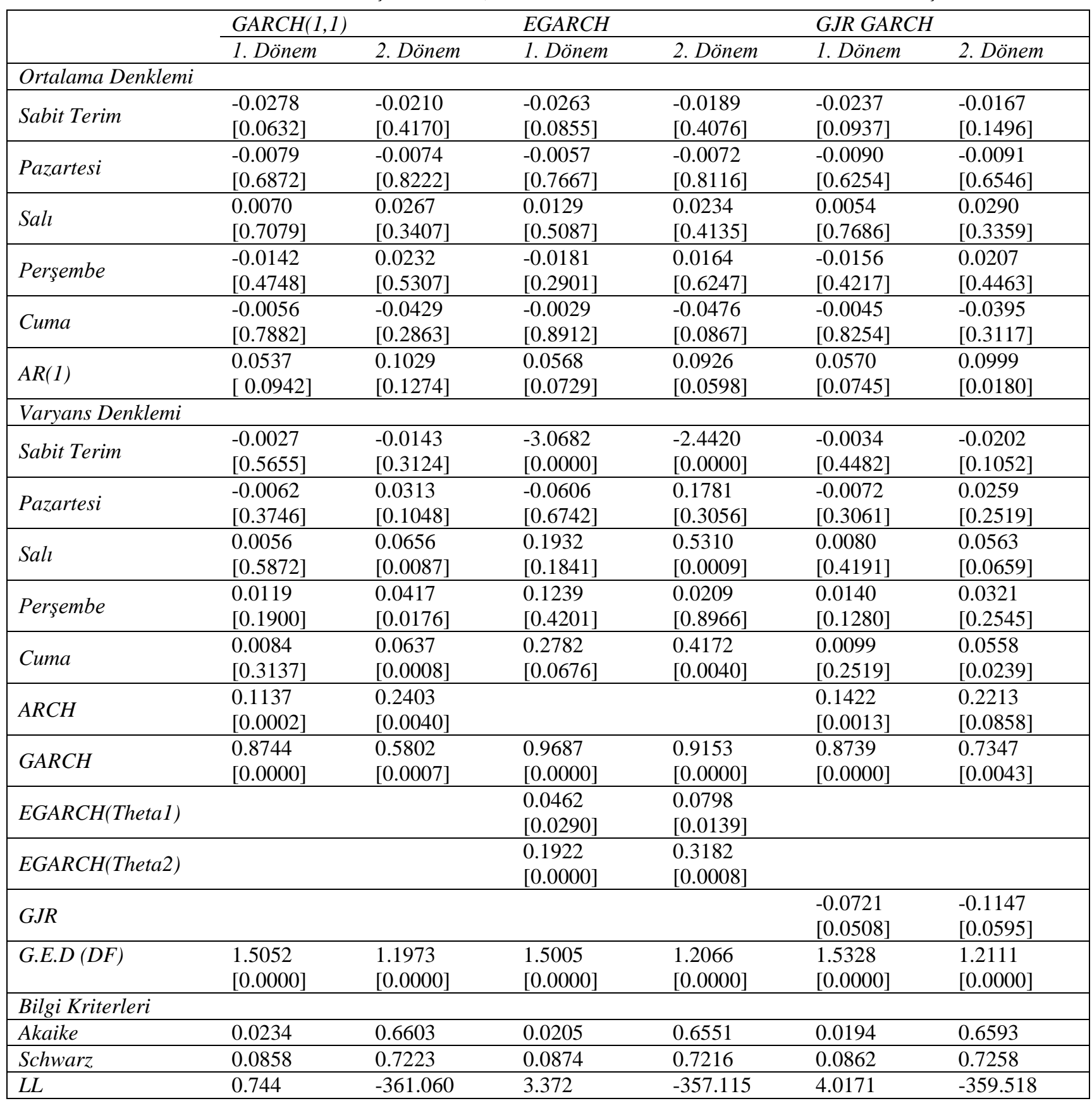

Not: Olasılık değerleri parantez içinde gösterilmiştir. LL: Log Olabilirlik değerini ifade etmektedir. Kukla değişken tuzağından kaçınmak amacıyla Çarşamba kukla değişkeni modele dahil edilmemiştir. Bu nedenle katsayı yorumları baz kategori olan Çarşamba gününe kıyasla yapılmaktadır.

Tablo 8'de USD getiri serisi için tahmin edilen GARCH, EGARCH ve GJR-GARCH modellerinden elde edilen artıklara ilişkin diyagnostik test sonuçları yer almaktadır. İlk olarak, ARCH-LM testi 2, 5 ve 10. gecikmeler için uygulanmıştır. Sonuçlar, 0.05 önem seviyesinde tüm gecikmeler için ARCH etkisinin ortadan kalktığını göstermektedir. 
Standardize artıklar kullanılarak elde edilen Ljung-Box otokorelasyon testi sonuçlarına göre 5, 10, 20 ve 50. gecikmeler için otokorelasyon sorunu bulunmamaktadır.

Tablo 8. USD Getiri Serisi GARCH, EGARCH ve GJR-GARCH Modelleri için Diyagnostik Test Sonuçları

\begin{tabular}{|c|c|c|c|c|c|c|}
\hline & \multicolumn{2}{|l|}{ GARCH } & \multicolumn{2}{|l|}{ EGARCH } & \multicolumn{2}{|c|}{ GJR-GARCH } \\
\hline & 1. Dönem & 2. Dönem & 1. Dönem & 2. Dönem & 1. Dönem & 2. Dönem \\
\hline$A R C H-L M(2)$ & $\begin{array}{l}0.0105 \\
{[0.9895]}\end{array}$ & $\begin{array}{l}1.3557 \\
{[0.2582]}\end{array}$ & $\begin{array}{l}0.14839 \\
{[0.8621]}\end{array}$ & $\begin{array}{l}2.0443 \\
{[0.1300]}\end{array}$ & $\begin{array}{l}0.1627 \\
{[0.8498]}\end{array}$ & $\begin{array}{l}2.6243 \\
{[0.0729]}\end{array}$ \\
\hline$A R C H-L M(5)$ & $\begin{array}{l}0.7674 \\
{[0.5733]}\end{array}$ & $\begin{array}{l}0.64893 \\
{[0.6624]}\end{array}$ & $\begin{array}{l}2.1030 \\
{[0.0627]}\end{array}$ & $\begin{array}{l}0.8815 \\
{[0.4927]}\end{array}$ & $\begin{array}{l}0.9666 \\
{[0.4370]}\end{array}$ & $\begin{array}{l}1.1653 \\
{[0.3242]}\end{array}$ \\
\hline$A R C H-L M(10)$ & $\begin{array}{l}0.4809 \\
{[0.9031]}\end{array}$ & $\begin{array}{l}0.80086 \\
{[0.6280]}\end{array}$ & $\begin{array}{l}1.1732 \\
{[0.3048]}\end{array}$ & $\begin{array}{l}0.7767 \\
{[0.6515]}\end{array}$ & $\begin{array}{l}0.6213 \\
{[0.7966]} \\
\end{array}$ & $\begin{array}{l}0.9921 \\
{[0.4482]}\end{array}$ \\
\hline$L B-Q(5)$ & $\begin{array}{l}7.4140 \\
{[0.1155]}\end{array}$ & $\begin{array}{l}2.51804 \\
{[0.6414]}\end{array}$ & $\begin{array}{l}7.7062 \\
{[0.1029]}\end{array}$ & $\begin{array}{l}2.3047 \\
{[0.6799]}\end{array}$ & $\begin{array}{l}7.6485 \\
{[0.1053]}\end{array}$ & $\begin{array}{l}1.8651 \\
{[0.7605]}\end{array}$ \\
\hline$L B-Q(10)$ & $\begin{array}{l}12.5182 \\
{[0.1856]}\end{array}$ & $\begin{array}{l}10.4580 \\
{[0.3146]}\end{array}$ & $\begin{array}{l}14.1907 \\
{[0.1157]}\end{array}$ & $\begin{array}{l}8.1025 \\
{[0.5238]}\end{array}$ & $\begin{array}{l}13.4518 \\
{[0.1432]}\end{array}$ & $\begin{array}{l}8.0490 \\
{[0.5292]}\end{array}$ \\
\hline$L B-Q(20)$ & $\begin{array}{l}16.5055 \\
{[0.6233]}\end{array}$ & $\begin{array}{l}15.7025 \\
{[0.6770]}\end{array}$ & $\begin{array}{l}18.4282 \\
{[0.4940]}\end{array}$ & $\begin{array}{l}12.9001 \\
{[0.84364]}\end{array}$ & $\begin{array}{l}18.3453 \\
{[0.4994]}\end{array}$ & $\begin{array}{l}13.3026 \\
{[0.8227]}\end{array}$ \\
\hline$L B-Q^{2}(5)$ & $\begin{array}{l}3.80462 \\
{[0.2833]}\end{array}$ & $\begin{array}{l}3.26234 \\
{[0.3529]}\end{array}$ & $\begin{array}{l}10.3988 \\
{[0.0342]}\end{array}$ & $\begin{array}{l}4.5826 \\
{[0.3328]}\end{array}$ & $\begin{array}{l}4.6156 \\
{[0.2022]}\end{array}$ & $\begin{array}{l}5.9446 \\
{[0.1143]}\end{array}$ \\
\hline$L B-Q^{2}(10)$ & $\begin{array}{l}4.71859 \\
{[0.7871]} \\
\end{array}$ & $\begin{array}{l}8.52006 \\
{[0.3843]}\end{array}$ & $\begin{array}{l}11.1164 \\
{[0.2678]}\end{array}$ & $\begin{array}{l}8.4731 \\
{[0.4872]}\end{array}$ & $\begin{array}{l}5.4672 \\
{[0.7066]}\end{array}$ & $\begin{array}{l}10.7251 \\
{[0.2177]}\end{array}$ \\
\hline$L B-Q^{2}(20)$ & $\begin{array}{l}10.0303 \\
{[0.9309]}\end{array}$ & $\begin{array}{l}53.1586 \\
{[0.0000]}\end{array}$ & $\begin{array}{l}16.9945 \\
{[0.5902]}\end{array}$ & $\begin{array}{l}44.0552 \\
{[0.0009]}\end{array}$ & $\begin{array}{l}11.5224 \\
{[0.8708]}\end{array}$ & $\begin{array}{l}31.6895 \\
{[0.0239]}\end{array}$ \\
\hline
\end{tabular}

Not: Olasılık değerleri parantez içinde gösterilmiştir. LBQ(5), LBQ(10) ve LBQ(20) Standardize Artıklar için Q istatistiklerini göstermektedir. $\mathrm{LBQ}^{2}(5), \mathrm{LBQ}^{2}(10)$ ve $\mathrm{LBQ}^{2}(20)$ Standardize Artık Kareler için Q istatistiklerini ifade etmektedir.

Tablo 9' da USD getiri serisi için tahmin edilen EGACRH model için işaret sapma testi; negatif büyüklük sapma testi; pozitif büyüklük sapma testi; üç etki için ortak test sonuçları verilmiştir. Bu test istatistikleri parametrik olmayan işaret ve büyüklük testleridir. Bu sonuçlara göre, birinci dönemde 0.10 önem seviyesinde işaret etkisi ve ortak etki istatistiki olarak anlamlıdır. Ancak ikici dönemde istatistiki olarak anlamlı bir işaret ve büyüklük etkisi bulunmamaktadır.

Tablo 9. Haber Etkisine Dayalı Diyagnostik Test

\begin{tabular}{|l|l|l|}
\hline & USD \\
\hline & 1. Dönem & 2. Dönem \\
\hline İşaret Sapma t-Testi & $1.9048[0.0568]$ & $0.4325[0.6653]$ \\
\hline Negatif Büyüklük Sapma t-Testi & $0.3287[0.7423]$ & $1.1133[0.2655]$ \\
\hline Pozitif Büyüklük Sapma t-Testi & $1.0359[0.3002]$ & $1.5943[0.1108]$ \\
\hline Ü̧̧ Etki için Ortak Test & $6.3641[0.0951]$ & $4.3124[0.2296]$ \\
\hline
\end{tabular}

Tablo 10'da EUR getiri serisi için tahmin edilen GARCH, EGARCH ve GJR-GARCH modellerine ait sonuçlar yer almaktadır. Her iki dönem için tahmin edilen GARCH modeline ilişkin sonuçlar incelendiğinde, ARCH ve GARCH parametrelerinin toplamının 1'den küçük değerli olduğu görülmektedir. Buna göre, GARCH model için durağanlık koşulu sağlanmıştır. Her iki dönem için ortalama denklemleri incelendiğinde, haftanın günlerine ilişkin kukla değişkeler istatistiki olarak anlamlı değildir. Buna göre, ortalama getiri bakımından haftanın günleri arasında anlamlı bir farklılık bulunmamaktadır. Koşullu varyans denklemlerinde ise, her iki dönem için Pazartesi ve Perşembe günleri 0.10 önem seviyesinde istatistiki olarak anlamlıdır. Buna göre, EUR getiri oynaklığı, Çarşamba gününe kıyasla, Pazartesi ve Perşembe günleri daha yüksektir. Birinci ve ikinci dönem için ARCH ve GARCH katsayıları pozitif değerli ve istatistiki olarak anlamlıdır. Buna göre belirli bir güne ait getiriler bir önceki güne ait getirilerden etkilenmektedir. Ayrıca, eğer belirli bir günde seride ortaya çıkan oynaklık şoku pozitif ise bir sonraki günde de pozitif oynaklık şoku ortaya çıkmaktadır. GED katsayısı istatistiki olarak anlamlı, pozitif değerli ve 2 değerinden küçüktür.

Tablo 10'da yer alan EGARCH modeller incelendiğinde, ilk dönemde haftanın günlerine ait kukla değişkenler istatistiki olarak anlamlı değilken ikinci dönemde sabit terim 0.05 önem seviyesinde istatistiki olarak anlamlıdır. Buna göre ortalama EUR getirisi üzerinde haftanın günü etkisi bulunmaktadır. Koşullu varyans denklemleri incelendiğinde, ilk dönemde sabit terim, Pazartesi, Perşembe ve Cuma günleri 0.05 önem seviyesinde istatistiki olarak anlamlıdır. Buna göre oynaklık, Çarşamba gününe kıyasla, Pazartesi, Perşembe ve Cuma günleri daha fazladır. İkinci dönem için yalnızca Salı günü 0.10 önem seviyesinde istatistiki olarak anlamlıdır. Buna göre, Salı günü Çarşambaya kıyasla oynaklık daha yüksek seviyededir. Her iki dönem için de işaret etkisini gösteren Theta 1 katsayısı 0.05 önem seviyesinde istatistiki olarak anlamlı ve pozitif değerlidir. Buna göre, pozitif şoklar negatif şoklara kıyasla daha fazla 
istikrar bozucu niteliktedir. Her iki dönem için GED katsayısı pozitif, 2 değerinden küçük ve istatistiki olarak anlamlıdır.

Tablo 10'de yer alan GJR-GARCH model ele alındığında, ilk dönem ortalama denkleminde yer alan haftanın günü kukla değişkenleri istatistiki olarak anlamlı değildir. Buna göre, ortalama EUR getirisi bakımından haftanın günleri arasında bir farklılık bulunmamaktadır. İkinci dönemde ise yalnızca sabit terim istatistiki olarak anlamlıdır. Koşullu varyans denklemi incelendiğinde, birinci dönemde Perşembe ve Cuma günleri; ikinci dönemde ise Perşembe günü 0.10 önem seviyesinde istatistiki olarak anlamlıdır. Dolayısıyla, ilk dönem Perşembe ve Cuma günleri, ikinci dönemde ise sadece Perşembe günü EUR oynaklığının Çarşamba gününe kıyasla daha fazla olması beklenmektedir. ARCH ve GARCH katsayıları istatistiki olarak anlamlıdır. Ayrıca GJR modelin geçerliliği için gerekli olan negatif olmama kısıtları da sağlanmıştır. Buna göre, GARCH $\geq 0 \mathrm{GARCH}+\mathrm{GJR} \geq 0$ olarak elde edilmiştir. Ancak her iki dönemde de katsayı istatistiki olarak anlamlı olmasına rağmen pozitif işaret beklentisini karşılamamaktadır.

Tablo 10. EUR Getiri Serisi için GARCH, EGARCH VE GJR-GARCH Model Sonuçları

\begin{tabular}{|c|c|c|c|c|c|c|}
\hline & \multicolumn{2}{|l|}{ GARCH } & \multicolumn{2}{|l|}{$E G A R C H$} & \multicolumn{2}{|c|}{ GJR GARCH } \\
\hline & 1. Dönem & 2. Dönem & 1. Dönem & 2. Dönem & 1. Dönem & 2. Dönem \\
\hline \multicolumn{7}{|l|}{ Ortalama Denklemi } \\
\hline Sabit Terim & $\begin{array}{l}-0.0142 \\
{[0.2354]}\end{array}$ & $\begin{array}{l}-0.0224 \\
{[0.1238]}\end{array}$ & $\begin{array}{l}-0.0091 \\
{[0.4329]}\end{array}$ & $\begin{array}{l}-0.0208 \\
{[0.0000]}\end{array}$ & $\begin{array}{l}-0.0107 \\
{[0.3447]}\end{array}$ & $\begin{array}{l}-0.0210 \\
{[0.0000]}\end{array}$ \\
\hline Pazartesi & $\begin{array}{l}-0.0021 \\
{[0.9087]}\end{array}$ & $\begin{array}{l}-0.0124 \\
{[0.5827]}\end{array}$ & $\begin{array}{l}-0.0057 \\
{[0.7677]}\end{array}$ & $\begin{array}{l}-0.0100 \\
{[0.5818]}\end{array}$ & $\begin{array}{l}-0.0006 \\
{[0.9712]}\end{array}$ & $\begin{array}{l}-0.0098 \\
{[0.1757]}\end{array}$ \\
\hline Sall & $\begin{array}{l}-0.0151 \\
{[0.3878]}\end{array}$ & $\begin{array}{l}-0.0019 \\
{[0.9260]}\end{array}$ & $\begin{array}{l}-0.0171 \\
{[0.3093]}\end{array}$ & $\begin{array}{l}0.0086 \\
{[0.6247]}\end{array}$ & $\begin{array}{l}-0.0151 \\
{[0.3440]}\end{array}$ & $\begin{array}{l}0.0003 \\
{[0.9599]}\end{array}$ \\
\hline Perşembe & $\begin{array}{l}-0.0209 \\
{[0.2605]}\end{array}$ & $\begin{array}{l}0.0087 \\
{[0.6890]}\end{array}$ & $\begin{array}{l}-0.0186 \\
{[0.2939]}\end{array}$ & $\begin{array}{l}0.0086 \\
{[0.1753]}\end{array}$ & $\begin{array}{l}-0.0218 \\
{[0.2254]}\end{array}$ & $\begin{array}{l}0.0097 \\
{[0.6487]}\end{array}$ \\
\hline Cuma & $\begin{array}{l}-0.0175 \\
{[0.3047]}\end{array}$ & $\begin{array}{l}0.0052 \\
{[0.8085]}\end{array}$ & $\begin{array}{l}-0.0201 \\
{[0.2832]}\end{array}$ & $\begin{array}{l}0.0108 \\
{[0.6766]}\end{array}$ & $\begin{array}{l}-0.0170 \\
{[0.3705]}\end{array}$ & $\begin{array}{l}0.0046 \\
{[0.3475]}\end{array}$ \\
\hline$A R(1)$ & $\begin{array}{l}0.1392 \\
{[0.0001]}\end{array}$ & $\begin{array}{l}0.0859 \\
{[0.0037]}\end{array}$ & $\begin{array}{l}0.1370 \\
{[0.0001]}\end{array}$ & $\begin{array}{l}0.0869 \\
{[0.0000]}\end{array}$ & $\begin{array}{l}0.1431 \\
{[0.0000]}\end{array}$ & $\begin{array}{l}0.0884 \\
{[0.0000]}\end{array}$ \\
\hline \multicolumn{7}{|l|}{ Varyans Denklemi } \\
\hline Sabit Terim & $\begin{array}{l}-0.0009 \\
{[0.8495]}\end{array}$ & $\begin{array}{l}-0.0132 \\
{[0.2514]}\end{array}$ & $\begin{array}{l}-3.2583 \\
{[0.0000]}\end{array}$ & $\begin{array}{l}-2.3738 \\
{[0.0000]}\end{array}$ & $\begin{array}{l}-0.0007 \\
{[0.8739]}\end{array}$ & $\begin{array}{l}-0.0079 \\
{[0.4900]}\end{array}$ \\
\hline Pazartesi & $\begin{array}{l}0.0132 \\
{[0.0707]}\end{array}$ & $\begin{array}{l}0.0322 \\
{[0.0583]}\end{array}$ & $\begin{array}{l}0.5030 \\
{[0.0014]}\end{array}$ & $\begin{array}{l}0.2317 \\
{[0.1878]}\end{array}$ & $\begin{array}{l}0.0117 \\
{[0.1043]}\end{array}$ & $\begin{array}{l}0.0253 \\
{[0.1424]}\end{array}$ \\
\hline Salı & $\begin{array}{l}-0.0010 \\
{[0.9249]}\end{array}$ & $\begin{array}{l}0.0304 \\
{[0.1468]}\end{array}$ & $\begin{array}{l}0.2358 \\
{[0.1101]}\end{array}$ & $\begin{array}{l}0.3043 \\
{[0.0564]}\end{array}$ & $\begin{array}{l}0.0003 \\
{[0.9716]}\end{array}$ & $\begin{array}{l}0.0218 \\
{[0.3430]}\end{array}$ \\
\hline Perşembe & $\begin{array}{l}0.0189 \\
{[0.0276]}\end{array}$ & $\begin{array}{l}0.0460 \\
{[0.0239]}\end{array}$ & $\begin{array}{l}0.3043 \\
{[0.0447]}\end{array}$ & $\begin{array}{l}0.1948 \\
{[0.2094]}\end{array}$ & $\begin{array}{l}0.0184 \\
{[0.0282]}\end{array}$ & $\begin{array}{l}0.0348 \\
{[0.0964]}\end{array}$ \\
\hline Cuma & $\begin{array}{l}0.0138 \\
{[0.1220]}\end{array}$ & $\begin{array}{l}0.0171 \\
{[0.3382]}\end{array}$ & $\begin{array}{l}0.3939 \\
{[0.0081]}\end{array}$ & $\begin{array}{l}0.1732 \\
{[0.2327]}\end{array}$ & $\begin{array}{l}0.0153 \\
{[0.0994]}\end{array}$ & $\begin{array}{l}0.0108 \\
{[0.5475]}\end{array}$ \\
\hline$A R C H$ & $\begin{array}{l}0.1633 \\
{[0.0002]}\end{array}$ & $\begin{array}{l}0.2366 \\
{[0.0000]}\end{array}$ & & & $\begin{array}{l}0.2196 \\
{[0.0029]}\end{array}$ & $\begin{array}{l}0.3084 \\
{[0.0007]}\end{array}$ \\
\hline$G A R C H$ & $\begin{array}{l}0.7009 \\
{[0.0000]}\end{array}$ & $\begin{array}{l}0.7047 \\
{[0.0000]}\end{array}$ & $\begin{array}{l}0.9229 \\
{[0.0000]}\end{array}$ & $\begin{array}{l}0.8986 \\
{[0.0000]}\end{array}$ & $\begin{array}{l}0.6961 \\
{[0.0000]}\end{array}$ & $\begin{array}{l}0.7245 \\
{[0.0000]}\end{array}$ \\
\hline EGARCH(Thetal) & & & $\begin{array}{l}0.0698 \\
{[0.0055]}\end{array}$ & $\begin{array}{l}0.1103 \\
{[0.0005]}\end{array}$ & & \\
\hline EGARCH(Theta2) & & & $\begin{array}{l}0.2195 \\
{[0.1133]}\end{array}$ & $\begin{array}{l}0.3849 \\
{[0.0000]}\end{array}$ & & \\
\hline GJR & & & & & $\begin{array}{l}-0.1172 \\
{[0.0585]}\end{array}$ & $\begin{array}{l}-0.1795 \\
{[0.0137]}\end{array}$ \\
\hline G.E.D (DF) & $\begin{array}{l}1.4300 \\
{[0.0000]}\end{array}$ & $\begin{array}{l}1.1379 \\
{[0.0000]}\end{array}$ & $\begin{array}{l}1.4435 \\
{[0.0000]}\end{array}$ & $\begin{array}{l}1.1559 \\
{[0.0000]}\end{array}$ & $\begin{array}{l}1.4542 \\
{[0.0000]}\end{array}$ & $\begin{array}{l}1.1459 \\
{[0.0000]}\end{array}$ \\
\hline \multicolumn{7}{|l|}{ Bilgi Kriterleri } \\
\hline Akaike & -0.1102 & 0.6394 & -0.1074 & 0.6335 & -0.1136 & 0.6338 \\
\hline Schwarz & -0.0478 & 0.7015 & -0.0406 & 0.7000 & -0.0468 & 0.7003 \\
\hline$L L$ & 76.242 & -348.8968 & 75.6446 & -344.884 & 79.164 & -345.037 \\
\hline
\end{tabular}

Not: Olasılık değerleri parantez içinde gösterilmiştir. LL: Log Olabilirlik değerini ifade etmektedir. Kukla değişken tuzağından kaçınmak amacıyla Çarşamba kukla değişkeni modele dahil edilmemiştir. Bu nedenle katsayı yorumları baz kategori olan Çarşamba gününe kıyasla yapılmaktadır.

Tablo 11'de EUR getiri serisi için tahmin edilen GARCH, EGARCH ve GJR-GARCH modellerinden elde edilen artıklara ilişkin diyagnostik test sonuçları yer almaktadır. İlk olarak, ARCH-LM testi 2, 5 ve 10. gecikmeler için uygulanmıştır. Sonuçlar, 0.05 önem seviyesinde tüm gecikmeler için ARCH etkisinin ortadan kalktığını göstermektedir. 
Standardize artıklar kullanılarak elde edilen Ljung-Box otokorelasyon testi sonuçlarına göre 5, 10, 20 ve 50. gecikmeler için otokorelasyon sorunu bulunmamaktadır. Yalnızca ikinci dönemde 10. gecikmede otokorelasyon sorunu bulunmaktadır. Ancak daha yüksek gecikmelerde otokorelasyon sorunu olmadığı görülmektedir.

Tablo 11. EUR Getiri Serisi GARCH, EGARCH ve GJR-GARCH Modelleri için Diyagnostik Test Sonuçları

\begin{tabular}{|c|c|c|c|c|c|c|}
\hline & \multicolumn{2}{|l|}{ GARCH } & \multicolumn{2}{|l|}{ EGARCH } & \multicolumn{2}{|c|}{ GJR-GARCH } \\
\hline & 1. Dönem & 2. Dönem & 1. Dönem & 2. Dönem & 1. Dönem & 2. Dönem \\
\hline$A R C H-L M(2)$ & $\begin{array}{l}0.1778 \\
{[0.8371]}\end{array}$ & $\begin{array}{l}0.6261 \\
{[0.5348]}\end{array}$ & $\begin{array}{l}1.3293 \\
{[0.2651]}\end{array}$ & $\begin{array}{l}0.5187 \\
{[0.5954]}\end{array}$ & $\begin{array}{l}0.058346 \\
{[0.9433]}\end{array}$ & $\begin{array}{l}0.4335 \\
{[0.6483]}\end{array}$ \\
\hline$A R C H-L M(5)$ & $\begin{array}{l}0.6919 \\
{[0.6296]}\end{array}$ & $\begin{array}{l}0.5018 \\
{[0.7751]}\end{array}$ & $\begin{array}{l}1.7498 \\
{[0.1205]}\end{array}$ & $\begin{array}{l}0.5445 \\
{[0.7426]}\end{array}$ & $\begin{array}{l}0.76075 \\
{[0.5782]}\end{array}$ & $\begin{array}{l}0.6203 \\
{[0.6843]}\end{array}$ \\
\hline$A R C H-L M(10)$ & $\begin{array}{l}0.5629 \\
{[0.8449]}\end{array}$ & $\begin{array}{l}0.6207 \\
{[0.7971]}\end{array}$ & $\begin{array}{l}1.1996 \\
{[0.2867]}\end{array}$ & $\begin{array}{l}0.5221 \\
{[0.8754]}\end{array}$ & $\begin{array}{l}0.55980 \\
{[0.8474]}\end{array}$ & $\begin{array}{l}0.6361 \\
{[0.7836]}\end{array}$ \\
\hline$L B-Q(5)$ & $\begin{array}{l}4.3943 \\
{[0.3552]}\end{array}$ & $\begin{array}{l}7.6498 \\
{[0.1052]}\end{array}$ & $\begin{array}{l}5.0940 \\
{[0.2777]}\end{array}$ & $\begin{array}{l}6.2598 \\
{[0.1805]}\end{array}$ & $\begin{array}{l}3.6131 \\
{[0.4608]}\end{array}$ & $\begin{array}{l}6.6519 \\
{[0.1554]}\end{array}$ \\
\hline$L B-Q(10)$ & $\begin{array}{l}6.7688 \\
{[0.6611]}\end{array}$ & $\begin{array}{l}18.8844 \\
{[0.0261]}\end{array}$ & $\begin{array}{l}7.1015 \\
{[0.6265]}\end{array}$ & $\begin{array}{l}17.1302 \\
{[0.0467]}\end{array}$ & $\begin{array}{l}6.5825 \\
{[0.6804]}\end{array}$ & $\begin{array}{l}18.3836 \\
{[0.0309]}\end{array}$ \\
\hline$L B-Q(20)$ & $\begin{array}{l}23.0884 \\
{[0.2334]}\end{array}$ & $\begin{array}{l}26.8182 \\
{[0.1089]}\end{array}$ & $\begin{array}{l}20.9949 \\
{[0.3370]}\end{array}$ & $\begin{array}{l}25.1453 \\
{[0.1558]}\end{array}$ & $\begin{array}{l}23.1224 \\
{[0.2319]}\end{array}$ & $\begin{array}{l}26.7388 \\
{[0.1108]}\end{array}$ \\
\hline$L B-Q^{2}(5)$ & $\begin{array}{l}3.2048 \\
{[0.3611]}\end{array}$ & $\begin{array}{l}2.5159 \\
{[0.4724]}\end{array}$ & $\begin{array}{l}8.5823 \\
{[0.0724]}\end{array}$ & $\begin{array}{l}2.6953 \\
{[0.6100]}\end{array}$ & $\begin{array}{l}3.5644 \\
{[0.3124]}\end{array}$ & $\begin{array}{l}3.0987 \\
{[0.3766]}\end{array}$ \\
\hline$L B-Q^{2}(10)$ & $\begin{array}{l}5.5599 \\
{[0.6963]}\end{array}$ & $\begin{array}{l}6.6192 \\
{[0.5782]}\end{array}$ & $\begin{array}{l}12.7822 \\
{[0.1727]}\end{array}$ & $\begin{array}{l}5.5179 \\
{[0.7870]}\end{array}$ & $\begin{array}{l}5.4917 \\
{[0.7039]}\end{array}$ & $\begin{array}{l}6.5400 \\
{[0.5869]}\end{array}$ \\
\hline$L B-Q^{2}(20)$ & $\begin{array}{l}10.0042 \\
{[0.9317]}\end{array}$ & $\begin{array}{l}14.5831 \\
{[0.6903]}\end{array}$ & $\begin{array}{l}19.3254 \\
{[0.4361]}\end{array}$ & $\begin{array}{l}14.5656 \\
{[0.7497]}\end{array}$ & $\begin{array}{l}9.3746 \\
{[0.9504]}\end{array}$ & $\begin{array}{l}14.1631 \\
{[0.7183]}\end{array}$ \\
\hline
\end{tabular}

Not: Olasılık değerleri parantez içinde gösterilmiştir. LBQ(5), LBQ(10) ve LBQ(20) Standardize Artıklar için Q istatistiklerini göstermektedir. $\mathrm{LBQ}^{2}(5), \mathrm{LBQ}^{2}(10)$ ve $\mathrm{LBQ}^{2}(20)$ Standardize Artık Kareler için $\mathrm{Q}$ istatistiklerini ifade etmektedir.

Tablo 12' de EUR getiri serisi için tahmin edilen EGACRH model için işaret sapma testi; negatif büyüklük sapma testi; pozitif büyüklük sapma testi; üç etki için ortak test sonuçları verilmiştir. Bu test istatistikleri parametrik olmayan işaret ve büyüklük testleridir. Bu sonuçlara göre, ilk dönemde 0.10 önem seviyesinde pozitif büyüklük ve ortak etki istatistiki olarak anlamlıdır. Buna göre EUR getiri serisi üzerinde pozitif haberler etkilidir. İlave olarak tüm etkiler bir arada seriyi etkileyebilmektedir. Ancak ikinci dönemde istatistiki olarak anlamlı bir işaret ve büyüklük etkisi bulunmamaktadir.

Tablo 12. Haber Etkisine Dayalı Diyagnostik Test Sonuçları

\begin{tabular}{|l|l|l|}
\hline & \multicolumn{2}{|l|}{ EUR } \\
\hline & 1. Dönem & 2. Dönem \\
\hline Işaret Sapma t-Testi & $1.2617[0.2070]$ & $0.0664[0.9470]$ \\
\hline Negatif Büyüklük Sapma t-Testi & $1.1137[0.2653]$ & $0.2928[0.7696]$ \\
\hline Pozitif Büyüklük Sapma t-Testi & $2.2319[0.0256]$ & $1.0986[0.2719]$ \\
\hline$\ddot{U}$ Ç Etki için Ortak Test & $6.7088[0.0817]$ & $1.3958[0.7065]$ \\
\hline
\end{tabular}

\section{Sonuç}

Bu çalışmada TRY/USD ve TRY/ EUR serilerinde haftanın günü etkisinin var olup olmadığı GARCH, EGARCH ve GJR-GARCH modelleri ile araştırılmıştır. USD ve EUR getiri serilerinde haftanın günü etkisi hem ortalama hem de oynaklık denklemleri için analiz edilmiştir. Analiz sonuçlarına göre, (1) USD getiri serisi için ilk dönemde ortalama getiri ve oynaklık üzerinde haftanın günü etkisi bulunmamaktadır. İkinci dönemde de ortalama getiri üzerinde haftanın günleri etkili değildir. Öte yandan, Salı, Perşembe ve Cuma günleri oynaklık Çarşamba gününe kıyasla daha yüksek seviyededir. Oynaklık üzerinde haftanın günü etkisi bulunmaktadır. (2) EUR getiri serisi için her iki dönemde ortalama getiri bakımından haftanın günleri arasında anlamlı bir farklılık bulunmamaktadır. EUR getiri serisindeki oynaklık ise, Çarşamba gününe kıyasla, Pazartesi ve Perşembe günleri daha yüksek seviyededir. Oynaklık üzerinde haftanın günü etkisi bulunmaktadır. (3) EGARCH model sonuçlarına göre, ikinci dönemde Cuma günü ortalama getiri Çarşamba gününe kıyasla daha düşüktür. Buna göre, ortalama getiri üzerinde haftanın günü etkisi vardır. Oynaklık ise, Çarşamba gününe kıyasla, ilk dönemde Cuma günü; ikinci dönemde ise Salı ve Cuma günleri daha fazladır. (4) EUR getiri serisi birinci ve ikinci dönem EGARCH model sonuçlarına göre, ortalama getiri üzerinde haftanın günü etkisi bulunmamaktadır. Öte yandan, Çarşamba gününe kıyasla, birinci dönemde Pazartesi, Perşembe ve Cuma günleri oynaklık daha fazladır. İkinci dönemde ise Salı günü Çarşamba gününe kıyasla oynaklık daha yüksek seviyededir. USD ve EUR getiri serileri için birinci ve ikinci dönemde, pozitif şoklar negatif şoklara kıyasla daha fazla istikrar bozucu 
niteliktedir. USD ve EUR serilerinin ortalama getirileri ve oynaklıkları arasında pozitif ilişki bulunmaktadır. (5) GJR model sonuçlarına göre, USD ve EUR ortalama getiri serileri için haftanın günleri arasında bir farklılık bulunmamaktadır. USD serisinde ikinci dönemde Çarşamba gününe kıyasla Salı ve Cuma günleri oynaklık daha fazladır. EUR serisinde ilk dönem Perşembe ve Cuma günleri, ikinci dönemde ise sadece Perşembe günü oynaklık Çarşamba gününe kıyasla daha fazladır.(6) Her iki getiri serisinde kaldıraç etkisi bulunmamaktadır. Bu bağlamda EGARCH ve GJR-GARCH sonuçları birbirini desteklemektedir.

Analiz sonuçlarına gore finansal piyasalarda gözlemlenen takvimsel anomalilerden biri olan ve piyasa etkinliğini bozan haftanın günü etkisinin TRY/USD ve TRY/ EUR serilerinde söz konusu dönem için Türk döviz piyasasında var olduğu sonucuna varılmıştır. Dolayısıyla söz konusu dönemde TRY/USD ve TRY/ EUR döviz kuru için döviz piyasasının "zayıf formda etkin" olmadığı yorumu yapılabilir.

Finansal piyasalarda işlem gören varlıkların fiyatlanmasında haftanın günü etkisi, ay etkisi ve tatil etkisi gibi takvimsel anomaliler oldukça s1k görülmektedir. Literatürde, Etkin Piyasalar Hipotezi ile uyuşmayan bu anomalilerin varlığının araştırıldığ çalışmalar genellikle hisse senedi piyasaları üzerine yoğunlaşmıştır. Döviz piyasalarında ortaya çıkabilecek takvimsel anomalilerin tespitine yönelik çalışmalar ise literatürde oldukça sınırlı sayıdadır. Bu yönüyle çalışmanın ilgili literature katkı sağlayacağı beklenmektedir. Çalışmada kullanılan yöntem yoluyla TRY/USD ve TRY/ EUR döviz kurları dışındaki diğer döviz kurları kullanılarak da başka çalışmalar yapılması ve finansal piyasalarda ortaya çıkan söz konusu takvimsel anomalilerin varlığının araştırılması mümkündür. 


\section{KAYNAKÇA}

Aydoğan, K.; Booth, G. 2003. “Calendar Anomalies in the Turkish Foreign Exchange Markets”, Applied Financial Economics, Vol 13; 353-360.

Barak, O.; Demireli, E. 2006. "IMKB’de Gözlemlenen Fiyat Anomalilerinin Davranışsal Finans Modelleri Kapsamında Değerlendirilmesi." 10. Ulusal Finans Sempozyumu, 1-4.

Bauwens, L., Hafner, C., ve Laurent, S. 2012. Wiley Handbooks in Financial Engineering and Econometrics Handbook of Volatility Models and Their Applications. USA: Wiley.

Bayraktar, A. 2012. "Etkin Piyasalar Hipotezi." Aksaray Üniversitesi İktisadi ve İdari Bilimler Fakültesi Dergisi, 4.1 (2012): 37-47.

Berument, H.; Coşkun, N.M.; Şahin, A. 2007. "Day of the Week Effect on Foreign Exchange Market Volatility: Evidence from Turkey", Research in International Business and Finance, Vol 21; 87-97.

Brav, A.; Heaton J.B. 2002. "Competing Theories of Financial Anomalies." The Review of Financial Studies 15.2 (2002): 575-606.

Champell, Y. J., Lo A.W.; Mackinlay, C. 1996. The Econometrics of Financial Markets, Princeton University Press.

Coats Jr, Warren L. 1981. "The Weekend Eurodollar Game." The Journal of Finance 36.3 (1981): 649-659.

Cornett, M.M.; Schwarz, T. V.; Szakmary, A.C. 1995. "Seasonalities and İntraday Return Patterns in The Foreign Currency Futures Market." Journal of Banking \& Finance, 19.5 (1995): 843-869.

Erdoğan, M.; Bekir E. 2010. "Hisse Senedi Piyasalarında Görülen Anomaliler ve Bireysel Yatırımcı Üzerine Bir Araştırma." Atatürk Üniversitesi Sosyal Bilimler Enstitüsü Dergisi, 14.2 (2010): 279-300.

Eyüboğlu, S.; Eyüboğlu K. 2018. "Türk Döviz Piyasasında Haftanın Günü ve Ocak Ayı Etkilerinin Araştırılması." Cumhuriyet Üniversitesi İktisadi ve İdari Bilimler Dergisi 18.1: 176-187.

Fama, E. F. 1970. "Efficient Capital Markets: A Review of Theory and Empirical Work", The Journal of Finance, Vol. 25, No. 2, (pp.383-417).

Glosten , L., Jagannathan, R., Runkle, D. 1993. "Relationship Between the Expected Value and Volatility of the Nominal Excess Returns on Stocks". Journal of Finance. 48:1779-1801.

Hilliard, J. E.; Tucker, A. L. 1992. "A Note On Weekday, Intraday, and Overnight Patterns in The Interbank Foreign Exchange and Listed Currency Options Markets." Journal of Banking \& Finance, 16.6 (1992): 1159-1171.

Kamstra, M. J., Kramer, L. A.; Levi, M. D. 2002 “ Losing Sleep at The Market: The Daylight-Savings Anomaly:Reply", The American Economic Review, 92(4), 1257-1263.

Khademalomoom, S., Narayan, P. K. 2019. "Intraday Effects of The Currency Market." Journal of International Financial Markets, Institutions and Money 58 (2019): 65-77.

Kumar, S. 2015. "Turn-Of-Month Effect In The Indian Currency Market." International Journal of Managerial Finance 11.2 (2015): 232-243.

Kumar, S. 2016. "Revisiting Calendar Anomalies: Three Decades Of Multicurrency Evidence." Journal of Economics and Business 86 (2016): 16-32.

Kumar, S.; Pathak, R. 2016. "Do the Calendar Anomalies Still Exist? Evidence from Indian Currency Market", Managerial Finance, Vol 42; 136-150.

Liano, K.; Kelly, G.W. 1995. "Currency Futures and the Turn-Of-Month Effect”, Global Finance Journal, Vol 6; 1-7.

Lo, A. W. 2007. Efficient Markets Hypothesis, The New Palgrave: A Dictionary of Economics, L. Blume, S. Durlauf, eds., 2nd Edition, Palgrave Macmillan Ltd., (pp.1-28).

Madura, J. 1989. Financial Markets and Institutions, West Publishing Co., Saint Paul.

Mcfarland, J.W.; Pettit, R.R.; Sung, S. K. 1982. "The Distribution of Foreign Exchange Price Changes: Trading Day Effects and Risk Measurement." The Journal of Finance, 37.3 (1982): 693-715.

Nelson, D.B. 1991. "Conditional Heteroskedasticity in Asset Returns: A New Approach”. Econometrica 59(2): $347-$ 370.

Özarı, Ç.; Turan, K.K. 2016. "Vadeli İşlem Piyasalarında Haftanın Günü ve Ocak Ayı Etkisi: Karşılaştırmalı Analiz (VIOB and BIST)." Uluslararası Sosyal Araştırmalar Dergisi 9.42 (2016): 1604-1619.

Pettengill, G. N. 2003, “A Survey of The Monday Effect Literatüre”, Quarterly Journal of Business and Economics, 42(3-4), 121-137.

Rodriguez, J. 2002. "Essays In Behavioral Finance", A Dissertation Presented to the Faculty of The C. T. Bauer College of Business University of Houston, In Partial Fulfilment of the Requairements for the Degree Doctor of Philosophy.

Sansar, N.G. 2016. "Değişen Finansal Akımlar: Rasyonalizmden Davranışsal Finans Yaklaşımına" İstanbul Gelişim Üniversitesi Sosyal Bilimler Dergisi, 3.2 (2016): 135.

Shleifer, A. Inefficient Markets: An Introduction to Behavioural Finance. OUP Oxford, 2000.

Sümer, E.; Aybar, Ş.B. 2016. "Etkin Piyasalar Hipotezinin, Finansal Piyasaları Açıklamadaki Yetersizliği ve Davranışsal Finans." Erzincan Üniversitesi Sosyal Bilimler Enstitüsü Dergisi 9.2 (2016): 75-84.

Thatcher, J. S.; Blenman, L.P. 2001. "Synthetic Trades and Calendar Day Patterns The Case of the Dollar/Sterling Markets." Financial Review 36.2 (2001): 177-200.

Tsay, R. S. 2010. Analysis of Financial Time Series. Hoboken, NJ: Wiley. 
Tufan, C.; Sariçiçek, R. 2013. "Davranışsal Finans Modelleri, Etkin Piyasa Hipotezi ve Anomalilerine İlişkin Bir Değerlendirme." Trakya University Journal of Social Science 15.2 (2013).

Yamori, N.; Kurihara, Y. 2004. "The Day-Of-The-Week Effect in Foreign Exchange Markets: Multi-Currency Evidence", Research in International Business and Finance, Vol 18; 51-57.

Yamori, N.; Mourdoukoutas, P. 2003. "Does The Day-Of-The-Week Effect In Foreign Currency Markets Disappear? Evidence From the Yen/Dollar market." The Japanese Finance: Corporate Finance and Capital Markets in.... Emerald Group Publishing Limited, 2003: 443-459.

Yu, H., Chiou, I.; Wagner, J.J. 2008. "Does The Weekday Effect of The Yen/Dollar Spot Rates Exist in Tokyo, London, and New York? An Analysis of Panel Probability Distribution." Applied Economics 40(20): 2631-2643. 